\title{
Optimalisasi Kemampuan Belajar Anak Berkebutuhan Khusus Melalui Pembelajaran Homeschooling
}

\author{
Optimizing Learning Ability Of Children With Special Needs Through \\ Homeschooling Learning
}

\author{
Iroma Maulida ${ }^{1}$, Umriaty \\ Program Studi Diploma III Kebidanan, Politeknik Harapan Bersama \\ 1Email: iroma.maulida@yahoo.co.id
}

\begin{abstract}
ABSTRAK
Salah satu permasalahan yang dapat jumpai pada anak-anak adalah keterlambatan perkembangan. Anak-anak dengan keterbatasan tersebut tentu memerlukan bentuk layanan pendidikan khusus yang memadai dan sesuai dengan karakteristik keterbatasan masing-masing anak, sehingga mampu membantu ABK dalam belajar. Salah satu bentuk layanan pendidikan tersebut adalah homeschooling program. Oleh karena itu peneliti tertarik untuk mengetahui bagaimanakah langkah-langkah yang ditempuh sekolah dalam menentukan strategi pembelajaran, jenis strategi pembelajaran yang dilakukan dan langkah-langkah dalam pengelolaan kelas yang dilaksanakan dalam homeschooling $\mathrm{ABC}$ 'D agar tujuan pembelajaran dapat tercapai. Jenis penelitian ini adalah observasional menggunakan metode kualitatif dengan rancangan disain studi kasus. Responden dalam penelitian ini berjumlah 5 orang yaitu kepala sekolah dan perwakilan guru/pendidik pada pembelajaran Homeschooling ABC'D, serta orangtua murid anak yang belajar di Homeschooling ABC'D kelas Mliwis. Hasil penelitian menunjukkan langkah-langkah yang dilaksanakan di Homeschooling ABCD dalam menentukan strategi pembelajaran siswa melalui tahapan: identifikasi atribut/karakteristik kendala pada anak, menentukan tujuan pengajaran apa yang harus bisa dicapai anak setelah selesai mendapatkan suatu pengalaman belajar, memilih strategi pembelajaran, memilihan materi/bahan yang sesuai untuk mencapai tujuan, uji strategi dan materi (mencobanya pada anak), melakukan evaluasi performansi /pengamatan pencapaian tujuan pada anak/siswa didik. Adapun Strategi Pembelajaran yang diterapkan di homeschooling ABCD adalah metode ABA, serta metode lainnya seperti metode analisis tugas, pengajaran bertahap dan latihan persepsi motorik. Pengelolaan kelas pada pembelajan homeschooling di Mliwis dilaksanakan dengan cara menempatkan siswa sesuai jenis hambatan anak serta disesuaikan pula dengan tahapan kemampuan anak dalam satu kelas. Salah satu saran yang dapat peneliti berikan adalah jika memungkinkan perlu adanya variasi pembelajaran dengan metode visual (video/film) untuk membantu mencapai tujuan pembelajaran.
\end{abstract}

Kata Kunci : Homeschooling, keterlambatan perkembangan

ABSTRACT

One of the problems that can be encountered in children is developmental delay. Children with these limitations certainly need the form of special education services that are adequate and in accordance with the characteristics of the limitations of each child, so they are able to help children with special needs in learning. One form of educational services is the homeschooling program. Therefore researchers were interested in knowing how the steps taken by schools in determining learning strategies, types of learning strategies undertaken and steps in classroom management implemented in $A B C^{\prime} D$ homeschooling so learning objectives can be achieved. This type of research was observational using qualitative methods with case study design. Respondents in this study amounted to 5 people, namely the principal and representatives of teachers / educators in learning ABC Homes, as well as parents of children who study at ABC Homes, Homes class Mliwis. The results showed the steps carried out at ABCD Homeschooling in determining student learning strategies through stages: identification of the attributes / characteristics of obstacles in children, determining what teaching goals children should be able to achieve after completing a learning experience, choosing learning strategies, choosing material / appropriate materials to achieve goals, test strategies and materials (try it on children), conduct performance evaluations / observe the achievement of goals on children / students. The Learning Strategy applied in ABCD homeschooling was the ABA method, as well as other methods such as the method of task analysis, gradual teaching and motor perception training. Classroom management in homeschooling learning in Mliwis was carried out by 
placing students according to the type of child barrier and also adapted to the stages of children's abilities in one class. One suggestion that researchers can provide is if possible the need for variations in learning with visual methods (video / film) to help achieve learning objectives.

Keywords: Home shcolling, development delays

\section{PENDAHULUAN}

Salah satu permasalahan yang dapat jumpai pada anak anak adalah keterlambatan perkembangan. CMV (Cytomegalo Virus) merupakan salah satu penyakit menular yang dapat menimbulkan keterlambatan tersebut, antara lain berupa keterlambatan berjalan, gangguan pendengaran sehingga menyebabkan keterlambatan berbicara maupun ukuran kepala lebih kecil, dan lain-lain. (CDC, 2007) Smith, 2006 dalam Istikhomah, Nurul. 2017 menjelaskan bahwa ukuran kepala yang lebih kecil tentu dapat menyebabkan kerusakan otak atau tidak berfungsinya sebagian sel otak yang dapat menyebabkan kesulitan belajar. Kesulitan belajar yang dimaksud adalah kesulitan dalam memproses informasi, khususnya dalam konsep matematika dan kebahasaan sehingga anak mengalami kesulitan dalam menguasai dan menggunakan kemampuan mendengar, berbicara, menulis, berfikir atau kemampuan matematis. Anak-anak dengan keterbatasan tersebut termasuk dalam katagori ABK (Anak Berkebutuhan Khusus) dan tentunya memerlukan bentuk layanan pendidikan khusus yang memadai agar mereka mampu mencapai tujuan pembelajaran. Salah satu bentuk layanan pendidikan tersebut adalah homeschooling program. Akan tetapi bentuk hambatan/kelainan pada masing-masing ABK berbeda-beda. Bagaimanakah pembelajaran di homeschooling bagi anak anak dengan berbagai macam jenis hambatan agar dapat mencapai tujuan pembelajaran bagi masing-masing anak? Oleh karena itu peneliti tertarik untuk mengetahui bagaimanakah langkah-langkah yang ditempuh sekolah homeschooling dalam menentukan strategi pembelajaran jenis strategi pembelajaran yang dilakukan dan langkah-langkah dalam pengelolaan kelas yang dilaksanakan dalam homeschooling ABC'D agar tujuan pembelajaran dapat tercapai?

\section{METODE PENELITIAN}

Penelitian ini merupakan penelitian observasional dengan metode kualitatif dan rancangan penelitian studi kasus. Responden dalam penelitian ini berjumlah 5 orang yaitu kepala sekolah dan 2 perwakilan guru/pendidik, serta 
orangtua murid 2 anak yang belajar di Homeschooling ABC'D kelas Mliwis. Pengambilan sampel dilaksanakan dengan cara purposive bagi guru maupun siswa, yaitu guru yang telah mengajar minimal 3 tahun dan siswa yang telah bersekolah minimal 3 tahun di Homeschooling ABC'D.

Data yang diambil meliputi tahapan dalam pemilihan strategi pembelajaran, strategi pembelajaran maupun pengelolaan kelas pada Homeschooling ABC'D. Data diambil melalui wawancara dan observasi serta dianalisis melalui tahapan reduksi data, penyajian data dan penarikan kesimpulan menggunakan triangulasi referensi yaitu dengan membanding hasil wawancara antara kepala sekolah, guru maupun orangtua siswa serta dibandingkan pula dengan hasil penelitian sejenis yang telah dipublikasikan sebelumnya.

\section{HASIL DAN PEMBAHSAN}

Hasil penelitian menunjukkan langkah-langkah yang dilaksanakan di pembelajaran Homeschooling ABCD dalam menentukan stratei pembelajaran siswa melalui beberapa tahapan. Tahapan yang pertama dilaksanakan berikut: “...saat mau masuk kami ada tes buat anak untuk melihat kemampuan anak. Lalu kami jelaskan pada orangtua anak hambatan yang dialami anak dan seputar pembelajaran yang akan kami lakukan....bila orangtuanya setuju maka anak kami terima." (R1)Dari hasil tes seleksi tersebut diketahui jenis hambatan anak dan kemampuan anak.

Hasil ini juga dijadikan pertimbangan dalam menentukan tujuan yang hendak dicapai anak dalam pembelajaran. Adapun tujuan pembelajaran bagi masing-masing anak dijelaskan dalam buku PPI (Program Pembelajaran Individual) sesuai dengan kemampuan awal anak. Hal ini dikemukan oleh Kepala Sekolah “ Kami ada program pembelajaran pada masingmasing anak untuk setiap bulannya dan bila tidak dapat dicapai akan diulang pada bulan berikutnya hingga kompetensi yang diharapkan pada anak tercapai.” (R1). Guru juga menambahkan “ Tujuan pembelajaran tidak hanya ditujukan pada kemampuan akademik anak seperti mampu membaca, berhitung dan menulis. Tetapi juga disertai target kemampuan anak dalam berperilaku (terapi perilaku). Misal untuk anak autis bagaimana mengurangi perilaku ekspresivenya." (R2) Juga penuturan dari guru lainnya berikut: “ Dalam 1 semester ada tema pembelajaran, seperti identifikasi 
anggota tubuh dan fungsinya, identifikasi angka, huruf vokal, huruf konsonan, 2 suku kata dan lai-lain sesuai dengan tematik capaian pembelajaran persemester /kurikulum 13. Jadwal itu disesuasaikan dengan kemampuan masing-masing anak dan ditulis dalam catatan perkembangan anak/anekdod. “ (R3).

Langkah berikutnya adalah memilih strategi pembelajaran serta materi/bahan yang sesuai untuk mencapai tujuan serta menerapkan strategi dan materi pembelajaran tersebut pada anak didik. Dari hasil observasi peneliti diketahui materi/bahan yang digunakan pembelajaran beraneka macam, mulai dari formulir berupa gambar dan tulisan, flash card, alat permainan puzle, dan lainlan yang digunakan untuk merangsang kemampuan anak dalam membaca, menulis, mengenal angka, identifikasi anggota dan fungsi tubuh, menempel, meronce, mengenal tempat-tempat umum, dan lain lain. Adapun beberapa contoh alat dan bahan pembelajaran terlihat pada gambar di bawah ini.

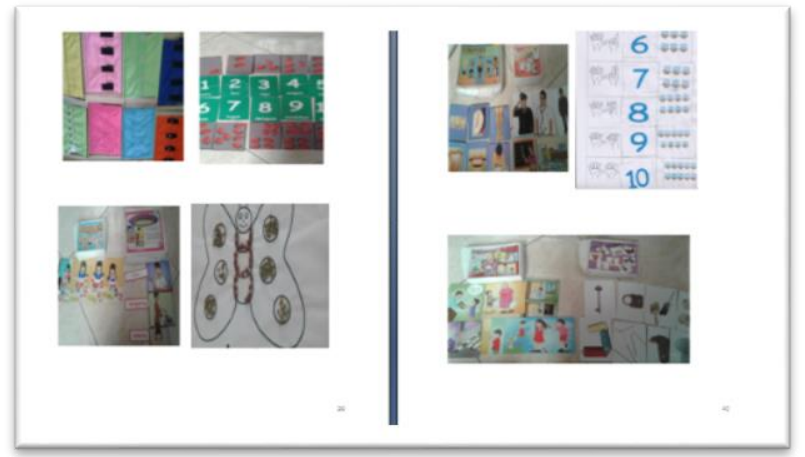

Gambar 1. Alat \& Bahan Pembelajaran

Penerapan materi dan strategi pembelajaran ditunjukkan antara lain melalui adanya jadwal pembelajaran seperti gambar dibawah ini

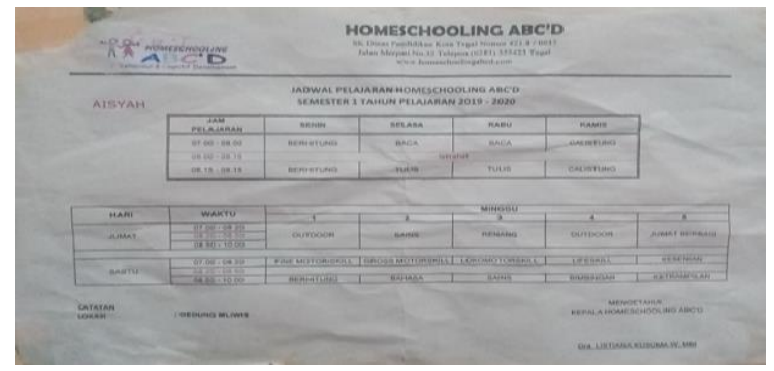

Gambar 2. Jadwal Pembelajaran

Langkah pembelajaran

berikutnya adalah melakukan evaluasi performans /pengamatan pencapaian tujuan pada anak/siswa didik.Evaluasi dilaksanakan oleh wali kelas melalui rapat koordinasi semua guru setiap minggu seperti penuturan guru berikut: "Jadi setiap minggu kemampuan anak itu dilihat melalui rapat guru.....kadang jum'at...kadang sabtu...kalau anak belum bisa maka diulangi program itu minggu depan." (R3) Hal ini didukung oleh pernyataan pengelola kelas berikut “ 
Setiap bulan kami evalusi juga kemampuan anak....jika bisa dicapai maka akan ditambah dengan target kemampuan/kompetensi yang lain."(R1). Jadi evaluasi juga dilaksanakan setiap bulan oleh pengelola kelas untuk melihat pencapaian perkembangan anak apakah sesuai dengan kompetensi yang hendak dicapai anak yang tertulis dalam PPI masing-masing anak.

Adapun strategi pembelajaran yang diterapkan di homeschooling ABCD adalah metode ABA, serta metode lainnya seperti metode analisis tugas, pengajaran bertahap dan latihan persepsi motorik. Strategi pembelajaran merupakan tahapan kegiatan pembelajaran dan pengaturan komponen/ materi pembelajaran untuk membantu siswa mencapai tujuan tertentu, menurut Dick dan Carey, 1994, dalam Istikhomah, N 2017. Dari wawancara dengan pengelola kelas Mliwis (R1) di ketahui bahwa strategi pembelajaran yang digunakan adalah metode ABA (Applied Behavior Analysis). Hal ini didukung penjelasan dari ibu guru (R2) melalui penuturannya berikut “ Di sini itu tidak hanya kemampuan akademiknya yang diajarkan tetapi juga kemampuan perilakunya agar lebih baik. ”(R2)
Adapun ABA menurut Danuatmaja merupakan metode modifikasi perilaku untuk membangun kemempuan yang baik serta menghilangkan hal-hal yang tidak baik melalui pendekatan perilaku secara langsung dengan lebih memfokuskan terjadinya perubahan secara spesifik baik berupa interaksi social, bahasa dan perawatan diri sendiri. ${ }^{4}$ Dari hasil wawancara dan pengamatan oleh peneliti dapat diketahui bahwa pembelajaran di homeschooling menerapkan metode ABA yang ditunjukkan pada beberapa kegiatan antara lain guru membiasakan mengucapkan salam saat menyambut kedatangan siswa untuk belajar serta mengajak untuk berkomunikasi, antara lain dengan sapaan berikut: “Assalamu”alaikum, selamat pagi, sudah maem belum? "Demikian juga saat siswa akan berpisah dengan orangtua/pengasuh siswa yang mengantar siswa maka siswa diajarkan untuk berkomunikasi dengan orangtua/pengasuh dengan kata-kata”, Dadah mama....(anak diminta untuk salim dengan orangtuanya serta melambaikan tangan)....hati-hati mama...."

Selain itu, anak juga diminta untuk melepaskan tas dan sepatunya 
sendiri serta meletakkannya pada tempat yang telah disediakan oleh sekolah. Hal ini menunjukkan bahwa pembelajaran mencoba melakukan kegiatan binadiri sehingga anak-anak diajarkan untuk mandiri dan mengurangi ketergantungan kepada oranglain dalam memenuhi kebutuhannya sehari-hari. Anak juga tidak diperkenankan menggunakan pempes saat pembelajarn di sekolah. Hal ini menunjukkan bahwa anak diajak untuk berada pada kondisi pada umumnya atau meminimalkan kebiasaan yang tidak wajar. Hal ini sesuai dengan salah satu tujuan penerapan metode ABA.

Setiap satu minggu sekali, siswa juga diajak untuk mengikuti pembelajaran outdoor yaitu kegiatan yang dilaksanakan di luar kelas, seperti ke taman bunga, perpustaakaan daerah, tempat berenang, dan-lain-lain. Hal ini menunjukkan bahwa pembelajaran di homeschooling berupaya untuk mengajak siswa untuk bersosialisasi ke dalam lingkungan yang umum. Kegiatan outdoor tersebut juga digunakan sebagai sarana untuk melatih kemampuan motorik anak, baik motorik kasar maupun motorik halus.

Salah satu orangtua siswa juga mengatakan bahwa setelah mengikuti pembelajaran di homeschooling maka respon anaknya meningkat, antara lain anaknya dapat mengutarakan keinginannya sendiri seperti penuturannya berikut "Anak saya setelah belajar di sini....udah bisa ngomong apa yang dia pingin ....kaya ...mama, aku mau makan ini...ada PR mama, yang ini jangan dihapus mama (sambil menunjukkan bukunya)." (R4)

Dari uraian tersebut di atas maka dapat diketahui bahwa pembelajaran di homeschooling $\mathrm{ABC}$ 'D menerapkan metode ABA karena berupaya untuk memenuhi tujuan pembelajaran yang diminta pada terapi dengan metode ABA, yaitu berupaya siswa dapat melakukan komunikasi dua arahsehingga kemampuan komunikasi anak meningkat mendekati kemampuan orang normal, melakukan upaya sosialisasi anak ke dalam lingkungan yang umum, baik menyangkut subyek/orang lain, lingkungan lain, instruksi, dan respon ana, menghilangkan /meminimalkan perilaku yang tidak wajar serta mengajarkan materi akademik agar kemampuan akademik anak dapat dikembangkan sesuai dengan tingkat intelegensia/IQ nya serta melakukan upaya kemampuan bantu diri atau bina diri dan ketrampilan lainagar anak tidak tergantung pada orang lain dalam 
memenuhi kebutuhannya. Kemampuan yang dimaksud seperti makan dan minum sendiri, mandi, memasang dan melepas pakaian, dan lain-lain.

Selain menggunakan metode metode ABA, pembelajaran di homeschooling $\quad A B C$ 'D juga menggunakan metode lainnya seperti metode analisis tugas dan pengajaran bertahap. Hal ini ditunjukkan antara lain melalui pembelajaran yang dilaksanakan bagi penderita autis berat seperti penuturan guru berikut ini "Untuk anak yang autis berat, kita tidak bisa mengajarkan satu persatu huruf untuk membaca.....tapi dicari dimana dia bisa menangkap pelajaran...misal melalui penglihatan. Kita sertakan gambar pada kata yang kita ingin ajarkan. kalau sudah hapal, baru dihilangkan gambarnya. Jika satu kata sudah hafal baru ditambah kata lain.....begitu terus, hafal, ditambah, hafal, ditambah. “(R2). Dari penuturan tersebut dapat diketahui bahwa pembelajaran yang diberikan pada $\mathrm{ABK}$ di Mliwis mengikuti langkah-langkah kecil sebagaimana dicontohkan untuk pembelajaran anak dengan autis berat. Bila kemampuan anak autis berat sudah dapat menghafal kata dan gambar yang memperjelas kata tersebut maka tahap berikutnya adalah menghilangkan gambar sehingga anak hanya melihat tulisan. Jika sudah hafal dengan 1 kata maka akan ditambahkan dengan menghilangkan gambar pada kata yang lain sehingga semakin lama kata yang diingat anak autis berat tersebut semakin banyak.

Pengelolaan kelas pada pembelajan homeschooling di Mliwis dilaksanakan dengan cara menempatkan siswa sesuai jenis hambatan anak serta disesuaikan pula dengan tahapan kemampuan anak dalam satu kelas. Misal untuk anak autis dimasukkan dengan anak autis. Untuk anak disleksia juga dengan anak disleksia. Selain itu, dalam 1 kelas pembelajaran maksimal terdiri dari 3 anak. Hal ini disampaikan oleh guru (Rerponden/ R2) dan dibenarkan oleh orangtua siswa (R4). Putra dari R4 sekarang berusia 7 tahun dan telah belajar di homeschooling sejak usia 3,5 tahun. Saat ini sedang belajar calistung (membaca, menulis dan berhitung) ditempatkan 1 kelas dengan siswa lain yang juga sedang belajar calistung dan baru masuk dalam pembelajaran homeschooling Mliwis. Hal ini menunjukkan bahwa pengelolaan kelas telah memperhatikan kesamaan kompetensi belajar siswa. 


\section{SIMPULAN DAN SARAN}

Langkah-langkah

dalam

pembelajaran di Homeschooling ABC'D

dalam menentukan strategi pembelajaran siswa melalui tahapan: identifikasi atribut/karakteristik kendala pada anak, menentukan tujuan pengajaran /memaparkan apa yang harus bisa dicapai anak, memilih strategi pembelajaran, pemilihan materi/bahan yang sesuai untuk mencapai tujuan, uji strategi dan materi (mencobanya pada anak), melakukan evaluasi performansi /pengamatan pencapaian tujuan pada anak/siswa didik.

Strategi Pembelajaran yang diterapkan di homeschooling ABCD adalah metode ABA, serta metode lainnya seperti metode analisis tugas, pengajaran bertahap dan latihan persepsi motorik. Pengelolaan kelas pada pembelajan homeschooling di Mliwis dilaksanakan dengan cara menempatkan siswa sesuai jenis hambatan anak serta disesuaikan pula dengan tahapan kemampuan anak dalam satu kelas.

Saran yang dapat peneliti berikan adalah jika memungkinkan untuk menginformasikan program / tujuan yang hendak dicapai masing-masing anak kepada orangtua agar orangtua siswa mengetahui program tersebut serta memiliki kesamaan arah/tujuan/tematik dengan pihak sekolah dalam memberikan pembelajaran kepada anaknya di rumah. Strategi pembelajaran di Homeschooling sudah baik dengan mempertimbangkan kompetensi anak dan tidakhanya ditujukan pada materi akademik tapi juga dilengkapi dengan terapi/perilaku agar mendekati keadaan normal sesuai perkembangan anak umumnya. Adapun mengenai alat pembelajaran peneliti menyarankan jika memungkinkan adanya variasi pembelajaran dengan metode visual (video/film) untuk membantu mencapai tujuan pembelajaran. Metode visual tersebut dapat digunakan untuk pemberian materi yang berkaitan dengan agama pada anak, seperti cerita nabi, tata cara berwudlu, sholat, dan lain-lain untuk menanamkan nilai-nilai moral (kejujuran untuk menanamkan nilai-nilai moral (kejujuran, berbagi, dan lain-lain).

\section{DAFTAR PUSTAKA}

Adzania Mirna. 2004. Merawat Balita Itu Mudah, Jakarta: Anak Prestasi Remaja hlm.43

AIH Roihah. 2015. Anak Berkebutuhan Khusua(ABK)diakses melaluihttp://etheses.uinmalang.ac.id/1484/6/11410112 Bab_2.pdf pada tanggal 17 April 2019 
Dwi Jayanti Agustina, 2014 Layanan Pendidikan ABK diakses melaluihttps://www.academia.ed u/24245783/LAYANAN_PENDI DIKAN_ABK pad tanggal 19 April 2019

Handojo, 2004. Petunjuk Praktis dan Pedoman Materi untuk Autism, UMM Press, Malang, hlm. 27

Hidayati, Ary. $2017 \quad$ Strategi Pembelajaran ABK Untuk peningkatan Kemampuan Berinteraksi Sosial di MI Amanah Tanggung Turen Malang, Skripsi, Fakultas Ilmu Tarbiyah dan Keguruan, Universitas Islam Negeri Maulana Malik Ibrahim, Malang

Istikhomah, Nurul. 2017. Strategi/Teknik Pembelajaran dan Pengelolaan Kelas, Fakultas Psikologi, Universitas 17 agustus 1945 surabaya

Maulida, 2017 diakses tanggal 27 Mei 2019padahttps://www.kompasian a.com/maulidaad/58dcc8f633977 3ec1beb7e17/metodepembelajaran-untuk-abk

Rofiah, F. 2014. Strategi Pembelajaran. diakses melalui http://www.eurekapendidikan.co $\mathrm{m} / 2014 / 12 /$ strategipembelajaran.html pada tanggal 18 April 2019

Rokhaniawati, 2017. Strategi Guru dalam Proses Pembelajaran Pada Kelas Inklusi di SD Pawiyatan Malang di akses pada https://media.neliti.com/.../25907 7-strategi-guru-dalam-prosespembelajaran-ef7eead7
US Departmnt of Human and Health Services. CDC .2017. 1. 1. Cytomegalovirus (CMV) and Congenital CMV Infection. https://www.cdc.gov/cmv/index. $\underline{\mathrm{html}}$

UU Republik Indonesia No 20 Tahun 2003 tentang Sistem Pendidikan Indonesia 